\title{
ON QUANTUM CRYPTOGRAPHY
}

Review Paper

DOI 10.7251/ZBKEN1901041J

COBISS.RS-ID 8274456

UDK 003.26:004.056.55

\section{Stevo Jacimovski ${ }^{1}$}

University of Criminal Investigation and Police Studies, Belgrade, Serbia

Jovan Setrajcic

Faculty of Sport, Union University, Belgrade

Jelena Lamovec

Institute of Chemistry, Technology and Metallurgy, Belgrade

\begin{abstract}
In the late twentieth century, human race entered the era of information technology (IT). The IT industry, which deals with the production, processing, storage and transmission of information, has become an integral part of the global economic system, a completely independent and significant sector of the economy. The dependence of the modern society on information technologies is so great that omissions in information systems may lead to significant incidents. Telecommunications are the key information technology industry. However, information is very susceptible to various types of abuse during transmission. The units for data storage and processing can be physically protected from anyone wishing harm, but this does not hold true for the communication lines that span hundreds or thousands of kilometers and are virtually impossible to protect. Therefore, the problem of information protection in the field of telecommunications is highly significant. Cryptology, particularly cryptography, deals with this issue. Quantum cryptography is a relatively new field ensuring safe communication between the sender and the recipient using the laws of quantum physics. This paper seeks to address the principles of the quantum distribution of a key for information encryption and the fundamental problems arising from the execution.
\end{abstract} protocols

Keywords: cryptography, algorithms, encryption, key, quantum physics,

\section{INTRODUCTION}

According to Anglo-Saxon tradition, the participants in the process of encryption and decryption are called Alice and Bob. An enemy, who wishes to disclose unauthorized information shared by Alice and Bob, is called Eva

\footnotetext{
${ }^{1}$ Stevo Jaćimovski: Full Professor, University of Criminal Investigation and Police Studies, Belgrade, Serbia, Belgrade. E-mail: stevo.jacimovski@kpu.edu.rs
} 
which is derived from eavesdropper (Bennett, 1992). The enemy, it is assumed, has unlimited computer resources and is familiar with the use of cryptographic methods, algorithms ${ }^{2}$, protocols ${ }^{3}$, and so on (Dugić, 2009).

The primary task of cryptography is to transform an initial text (plaintext) into an arbitrary string of characters called a cryptogram. The number of characters in the plaintext and the cryptogram may differ. The secrecy of the encryption algorithm itself cannot, in principle, ensure the unconditional security of the cryptograms, as it is assumed that Eva (the enemy) has infinitely large computer resources. Therefore, public key algorithms are used nowadays. The security of modern cryptosystems is based on the secrecy of a small item of information called a key, rather than on the secrecy of an algorithm. The key is used to manage the encryption process and should be easily changeable at any time. At the end of the nineteenth century, the Dutch scientist Kirchhoff formulated a rule by which the security of a key is ensured if the entire encryption system, other than the secret key, that is, the information that manages the process of cryptographic transformation, becomes known to the enemy, (Kilin, Horosko \& Nizovcev, 2007).

\section{SYMMETRIC ENCRYPTION SYSTEM}

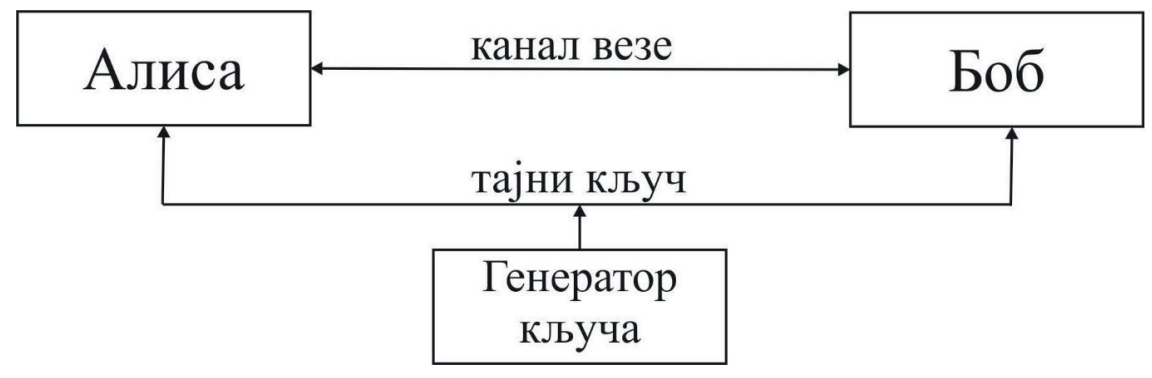

Figure 1. Structure of symmetric cryptosystems ${ }^{4}$

In symmetric cryptosystems, the sender and the recipient use the same secret key (Figure 1). An item of information is also encrypted and decrypted with this secret key. The key must be periodically updated and distributed at the same time to both the sender and the recipient. The process of distributing secret keys among the regular participants in the information exchange is a very complex process. If an illegitimate user (Eve) had the secret key, it would

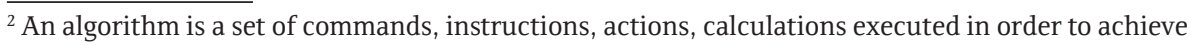
a result of initial data.

${ }^{3}$ A protocol is a set of actions (instructions, commands, calculations, algorithms) executed in a particular order by two or more actors with the aim of achieving a result.

${ }^{4}$ Translator's note: Alice - link channel- Bob; secret key; key generator. 
enable the knowledge of the information exchanged between Alice and Bob (Румянцев, Голубчиков 2009).

Symmetric cryptographic algorithms provide a high level of protection, as long as the key is only known to the sender and the recipient of the message. Therefore, the basic measure of the security of symmetric algorithms is the method of key distribution. The well-known and most widespread symmetric algorithm is DES and an improved version of 3 DES (Čisar, 2015).

This problem has previously been solved by a non-cryptographic method - by transferring the key to the physically protected eavesdropping channels. However, the creation of such a channel and its maintenance in operational readiness in case of an urgent need for a key transfer is very long and costly. Therefore, in the conditions of a constant increase in the intensity of information flows, this key distribution method has become less acceptable and satisfactory.

The problem has been successfully solved within modern cryptography. There are two ways to solve the key distribution: mathematically and physically. The mathematical method is realized by using a two-key based protocol or public-key cryptography. The physical way is realized by means of quantum cryptography.

ASYMMETRIC ENCRYPTION METHOD

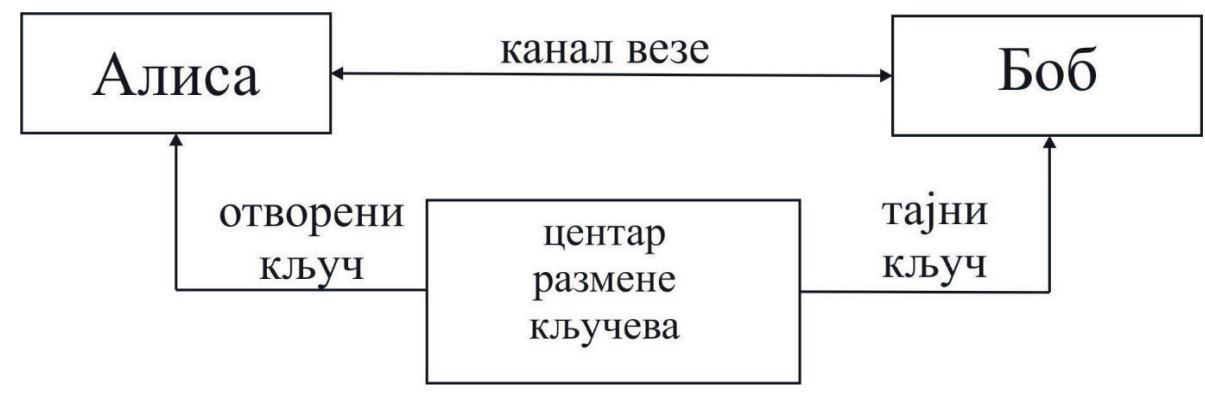

Figure 2. Structure of asymmetric cryptosystems ${ }^{5}$

Asymmetric cryptosystems use two keys - Figure 2. The first key is public and is available to all users of the information exchange. Information is encrypted with this key. Only the recipient (Bob) has the second secret key. Decrypting information with the public key is impossible. Also, the decryption key cannot be determined by using public key encryption (Румянцев \& Голубчиков, 2009).

\footnotetext{
${ }^{5}$ Translator's note: Alice - link channel - Bob; public key - key exchange center - secret key.
} 
In 1976, the scheme of asymmetric cryptography was proposed by Diffie and Hellman, Stanford University. If Alice and Bob want to establish a secret key, it is enough to follow this protocol (Jakus, 2016):

- Alice generates a random number $A$, computes $P=e^{A}$ and sends $P$ to Bob

- Bob generates a random number $\mathrm{B}$, computes $Q=e^{B}$ and sends $\mathrm{Q}$ to Alice.

Then Alice and Bob compute the secret key, K, as shown in Figure 3.

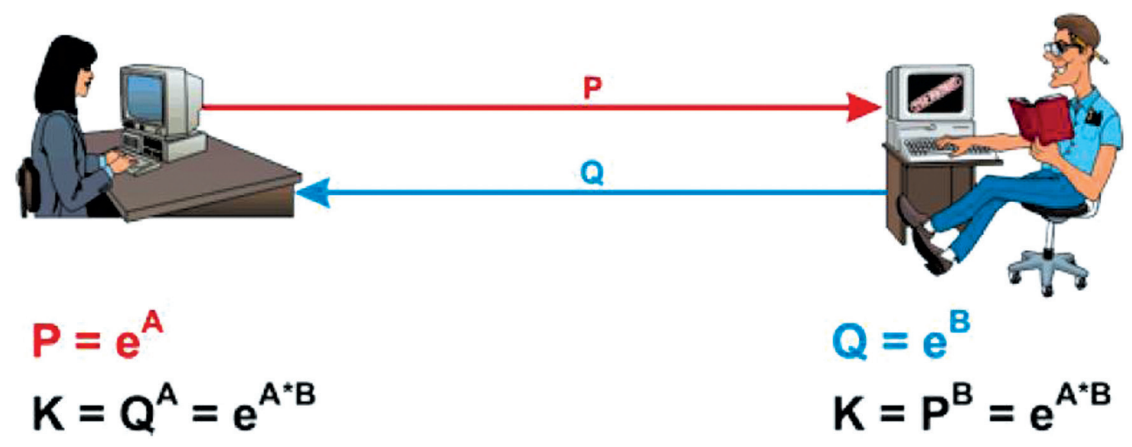

Figure 3. Diffie-Hellman protocol

Suppose Eva has P and Q. Can she compute K? To compute K, Eva must compute A or B because she can then repeat the computation of the key in the same way as Alice or Bob can. The idea is that the calculation A or B requires computing the discrete logarithm:

$$
A=\ln P, B=\ln Q
$$

for which there is no effective way (Stipčević, 2007). The security of the Diffie-Hellman method is based on the complexity of the discrete logarithm. The most famous algorithm within the group of asymmetric cryptographic methods is the RSA.

In the first case, different keys are encrypted and decrypted in the twokey based protocol, so there is no need to keep the secret key secure. However, due to the extremely low performance characteristics and exposure to the special types of attacks, such ciphers have proved inappropriate to close direct user information. Instead, asymmetric ciphers are used as part of combined

42 schemes, when a string of data is encrypted with a symmetric cipher on a onetime key, which is encrypted with a two-key cipher and is transmitted in this form along with the data.

In the second case, in public-key cryptography, the schemes for the distribution of the key over open communications channels solve the same problem in a slightly different way: during an interaction, two participants 
exchanging information generate a shared secret key, which is then used to encrypt the data being transferred using a symmetric cipher. Furthermore, intercepting information in a channel during a generating session of such a key does not allow the enemy to obtain the key by himself or herself.

The security of two-key cryptosystems is based on a slow technical progress. Their security is based on the problem of factorizing large numbers and computing discrete logarithms in certain final groups. These problems are believed to be "tough" in the sense that they might be solved by guessing all possible solutions (keys), with a number of steps increasing exponentially with the key length.

Secrecy in the modern world is based on the idea that something is computer-secure, in other words, it is secure in the sense that it would take too much computer time and power to break the cipher (Vedral, 2014). Finding a factor for large numbers is a difficult problem. Let us imagine the number 100 . What are its factors? Two times 50 equals 100 . But this is also true for 4 times 25 , or 5 times 20 or 10 times 10 . The number of factors grows rapidly and finding all of them poses a significant difficulty to every modern classical computer.

Nevertheless, with the expected emergence of quantum computers for which rapid factoring algorithms have been developed, the cryptographic systems based on the mathematical cryptographic methods can be compromised.

The procedure for this was developed by Peter Shore (Shor, 1994) who created an algorithm according to which a quantum computer can exist simultaneously in many different states, as it uses the quantum superposition principle. Let us imagine a single computer in a superposition, which is simultaneously at different locations. In each of these locations, we can configure a computer to share our number with another number to search for factors. In this way, we get an extremely rapid acceleration of the solution to the factorization problem, given that one quantum computer now simultaneously performs all these divisions, one at each spatial location. According to experts, a quantum computer that can break the RSA crypto system will be designed in about 15-25 years.

It is precisely for this reason that the idea of protecting information must be sought in, colloquially speaking, "hardware", that is, by using the laws of quantum mechanics for protection.

Therefore, the need to protect cryptosystems has arisen for other reasons. The solution of key distribution is realized in quantum cryptography based on the laws of physics (Jaćimovski \& Šetrajčić, 2016).

The basic arguments for this are twofold:

- It is impossible to copy an unknown quantum state

- Without perturbation, it is impossible to have information about non-orthogonal quantum states (in other words, when accessing an information channel, Eva changes the status of the information holders) 
Quantum cryptography uses the uncertainty of the quantum world during the measuring process, the so-called Heisenberg's uncertainty principle (Heisenberg, 1974). With quantum physics, a communication channel which cannot be eavesdropped without interfering with the transmission can be established. Two users who communicate with each other can always detect the presence of the third party trying to discover the key.

Also, an eavesdropper cannot copy unknown quantum bits, the so-called qubits, that is, unknown quantum states, because of the no-cloning theorem. Quantum cryptography is only used to generate and distribute a key, rather than to transmit messages. The generated key can thus be used in a cryptosystem for encryption and decryption.

In this way, quantum cryptography allows for relatively fast key exchange and the detection of Eve's attempts to enter the link channel. Note that the occurrence of errors during the transmission and reception of quantum states does not necessarily lead to the loss of secrecy. A critical error is defined for each protocol of quantum cryptography, above which secrecy is not ensured. If the error level (usually expressed in terms of percentages) is below the critical level, then the error correction protocols and the subsequent compression of the remaining bits are used to create the key. Following these procedures, Eva has as much information about the key as Alice and Bob want her to have (Picek \& Golub, 2009).

Presently, three forms of quantum state encryption are used in quantum cryptography: polarization encoding, phase enciphering and encoding using time shifts. This paper demonstrates the procedure for the polarization encoding of quantum states, the so-called BB84 protocol, and elaborates the E91protocol. Other protocols of quantum cryptography are also used.

\section{Example of the BB84 protocol without noise}

The BB84 protocol (Bennett \& Brassard, 1984) is the historical first protocol for quantum key distribution (Kilin, Khoroshko \& Nizovtsev, 2007), whose security is based on the principles of quantum mechanics, making it absolutely safe if there is no noise in the quantum channel. The absence of noise in a given situation assumes that the quantum state of particles does not change along the quantum channel.

The BB84 protocol is formulated in the language of individual photons,

44 (Figure 4), although it can be applied to other realizations of a qubit. To encode information, four polarization states forming two interconnected nonorthogonal bases are used in the protocol: rectangular $|\leftrightarrow|$ and diagonal $|\uparrow\rangle$

$$
|\swarrow\rangle=(|\leftrightarrow\rangle+|\uparrow\rangle) / \sqrt{2} \quad|\nwarrow\rangle=(|\leftrightarrow\rangle-|\uparrow\rangle) / \sqrt{2}
$$




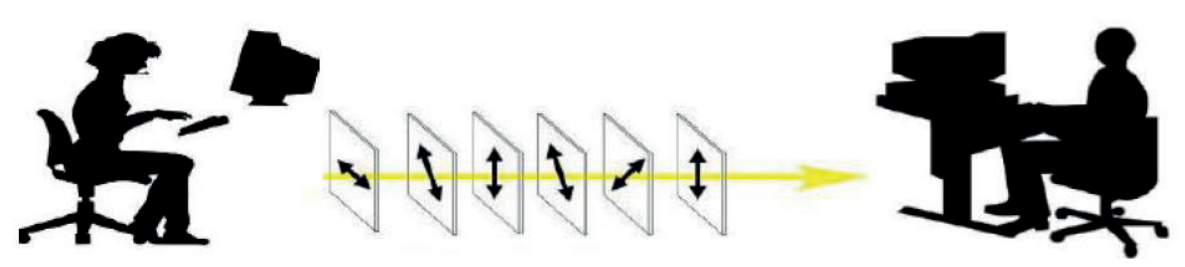

Quantum channel - sending polarized photons

Figure 4. The BB48 protocol demonstration

The essence of the BB84 protocol is that one of the users (Alice) randomly selects a series of bits (stage 1 ) and a series of bases (stage 2 ) and then sends a user (Bob) a string of photons (stage 3 ) each of which encodes one bit from the selected string in the base corresponding to the prime number of that bit, where the states $|\leftrightarrow\rangle|\langle\rangle\rangle$ are encoded into (0) zero, and the states $|\Delta\rangle \mid\langle\rangle$ into one (1). In obtaining a photon, Bob randomly selects the measurement base (rectangular or diagonal) for each photon and independently of Alice, (stage 4), analogously interprets the result of his measurement for each photon in two ways, as a zero or one (stage 5). In accordance with the laws of quantum mechanics and following the measuring of the diagonal photon in a rectangular base, its polarization turns into the horizontal or vertical line and vice versa, with random results. In this way, Bob obtains the results coinciding with the state of the photons sent in about half the cases (50\%), that is, when he correctly hits the base.

The next stage of the protocol is realized via a public channel, through which Alice and Bob can openly convey classical information to each other. At this stage, we assume that Eva can listen to the announcements by both parties, but she cannot change them or send notifications instead of them. To begin with, Alice and Bob determine (via a public channel) which photons were successfully obtained by Bob and which of them were measured in the correct base (stages 6 and 7). After that, Alice and Bob have the same bit values encoded in these photons, regardless of the fact that this information has never been established in the open communication channel (stage 8 ). In other words, each of these photons carries a bit of random information, which is known only to Alice and Bob and no one else. Information about the photons measured in the wrong base is rejected, so Alice and Bob get the so-called sieved key, which, in the event that Eva did not intercept the information, should be the same for both parties. 
Table 1. Example of the realization of the BB84 protocol. States $\left|Z^{7}\right\rangle\left|k^{7}\right\rangle$ encrypt (0) zero, while states $|\hat{\psi}\rangle|\Sigma\rangle$ encrypt one (1). Rectangular and diagonal bases are indicated by $\otimes$ and by $\otimes$.

\begin{tabular}{|l|l|l|l|l|l|l|l|l|l|}
\hline Stage 1 & $\begin{array}{l}\text { Random bit transmission } \\
\text { (Alice) }\end{array}$ & 0 & 1 & 1 & 0 & 1 & 1 & 0 & 0 \\
\hline Stage 2 & $\begin{array}{l}\text { Random bit transmission } \\
\text { (Alice) }\end{array}$ & $\otimes$ & $\otimes$ & $\otimes$ & $\oplus$ & $\oplus$ & $\otimes$ & $\otimes$ & $\oplus$ \\
\hline Stage 3 & $\begin{array}{l}\text { Polarization of photons } \\
\text { distributed along the } \\
\text { quantum channel }\end{array}$ & $\searrow$ & & $\nwarrow$ & $\leftrightarrow$ & $\uparrow$ & & $\nwarrow$ & $\leftrightarrow$ \\
\hline Stage 4 & $\begin{array}{l}\text { Randomly received bases } \\
\text { (Bob) }\end{array}$ & $\oplus$ & $\oplus$ & $\otimes$ & $\oplus$ & $\oplus$ & $\oplus$ & $\oplus$ & $\oplus$ \\
\hline Stage 5 & Bits received by Bob & 0 & 0 & 1 & 1 & 1 & 0 & 0 & 0 \\
\hline Stage 6 & $\begin{array}{l}\text { Bob informs Alice about } \\
\text { the bases of reception }\end{array}$ & $\oplus$ & $\otimes$ & $\otimes$ & $\otimes$ & $\oplus$ & $\oplus$ & $\oplus$ & $\oplus$ \\
\hline Stage 7 & $\begin{array}{l}\text { Alice tells Bob which of } \\
\text { their bases are harmonized }\end{array}$ & & & & & & & & \\
\hline Stage 8 & Sieved key & & & 1 & & 1 & & & 0 \\
\hline Stage 9 & $\begin{array}{l}\text { Bob discovers a portion of } \\
\text { bits }\end{array}$ & & & & & 1 & & & \\
\hline Stage 10 & Alice confirms it & & & & & & & & \\
\hline Stage 11 & $\begin{array}{l}\text { Sieved key after error } \\
\text { assessment }\end{array}$ & & & 1 & & & & & 0 \\
\hline
\end{tabular}

Suppose Eva is eavesdropping on a quantum channel. Due to the random selection of a rectangular or diagonal base, Eva influences the information in such a way that it changes the bits of the sieved key, which would have to be the same for Alice and Bob if there was no Eve. No measurement of the photons performed by Eve gives more than one half of the bit information encrypted by this photon; any such measurement gives $b$ bits of information $(b<1 / 2)$ and is not in compliance with the probability which is ultimately equal to $b / 2$ if the measured photon or its replacement is measured in the initial base by Bob. Alice and Bob can check if someone is eavesdropping on them by openly comparing a portion of bits (stages 9 and 10) for which they must have the same information, although these bits cannot, any longer, be used for the secret key. The position of the bits being compared should be a random subset of

46 the properly measured bits so that the presence of Eve must be noticed. If all the bits compared match, it is clear that there was no eavesdropping, and the remaining bits properly measured can be used for the secret key encryption (stage 11) and transmission over the open channel.

Once this key is used, Alice and Bob repeat the procedure to create a new secret key. 
The BB84 protocol would be threatened if Eve is able to perform the following interventions on the quantum channel (Markagić, 2012):

1. To measure the polarization of the photon sent by Alice, reproduce the same one and send it to Bob

2. To reproduce the photons sent by Alice

In the first case, Eva would have the same information that Alice and Bob had, so at the end of the procedure they would have the same key. However, Alice uses photons from the conjugated bases, in other words, there is no orientation of a polarizer with which Eva could with certainty distinguish the polarization of photons. In the second case, Eva wants to assure the polarization of the photons with a number of differently oriented polarizers. However, the reproduction of an unknown quantum state is not possible due to the no-cloning theorem.

In the communication process between Alice and Bob, a portion of the photons accurately measured is likely to be detected incorrectly. Also, if Eva attempts to measure the photons sent by Alice before they reach Bob, errors are likely to occur due to the fact that Eva is attempting to measure the data pertaining to the polarization of photons. These two situations cannot be distinguished: natural or artificial sounds look the same. As a result, Alice and Bob agree on a smaller cryptographic key in three phases viz. error assessment, information leverage and privacy enhancement.

\section{The E91 protocol (Ekert, 1991)}

Further, the improvement of cryptosystem reliability can be achieved using the Einstein-Podolsky-Rosen (EPR) effect (Einstein, Podolsky \& Rosen, 1935). The EPR effect occurs when a spherical symmetric atom radiates two photons in opposite directions to two observers. The photons are emitted with an unspecified polarization, but due to the symmetry of their polarization, they are always opposite (the quantum interference effect). An important feature of this effect is that the polarization of photons becomes known only after having been measured. Based on the EPR, Ekert proposed a crypto-scheme guaranteeing the security of the key transfer and storage. The sender generates a number of the APR photon pairs and leaves one photon from each pair for himself or herself, and sends the other one to his or her partner. At the same time, if the registration efficiency is close to the unity, when the sender receives the value of polarization 1 , his or her partner will register the value 0 and vice versa. Clearly, in this way, partners, whenever necessary, can get identical pseudo-random code sequences. Practically, the implementation of this scheme is problematic due to the low efficiency of recording and measuring the polarization of one photon. 


\section{CONCLUSION}

The task of cryptography is the exchange of secret messages. There are traditional methods that practically guarantee a secure communication (between Alice and Bob) if the secret decryption key is known to both parties, and at the same time, the key is not known to anyone else, even the potential enemy Eve.

It is this presumption of the secrecy of the "secret key" that is the weakest link in classical cryptography. The only task of quantum cryptography is to ensure a secret key. Thus, in quantum cryptography, not only messages are exchanged via the so-called quantum channel, but also secret keys. Today, there are already commercial devices as well as dozens of implementations of public and corporate secure network communications using the quantum key distribution technologies. The advantage of these technologies is the unconditional security based on the phenomena of quantum mechanics. Today, it is almost possible, with the unconditional security, to generate and distribute a secret key between two parties connected by optical fibers at distances up to 150 kilometers in a few seconds. Eavesdropping on communications by a third party does not lead to the revealing of a secret, but only to the reduction of the speed of key generation, with both parties immediately knowing that the line is being actively eavesdropped. The main disadvantage of these systems is the limited key generation speed, which depends directly on the distance of the participants, the inability to increase the signal or transmission through a type of relay, practical limitations solely on fiber optic communications, as well as the cost of system implementation (Ijačić, 2014).

In ideal systems of quantum communication, the interception of data is impossible, as the participants in the exchange of information immediately identify the interception as errors occurring in the transmission. However, the actual systems are different from the ideal ones.

Unlike the ideal quantum communication system, the actual quantum communication systems are unable to ensure the absolute secrecy of the data transmitted, due to the fact that there is a fond of its own errors in the system, behind which the attempts to intercept information can be hidden, as well as the attenuation of communication channels due to the necessity of using multiphoton pulses. The use of strong photon pulses leads to the dampening of the transmission of information enabling the interception of silent data. This is a factor that cannot practically be removed, as the quality of the channel through which the information is transmitted cannot always be controlled.

48 However, before the quantum communication systems is applied in practice, a number of technical difficulties need to be solved, such as the development of stable sources of single photons and single-photon detectors that would operate in a normal temperature range and should not be cooled by liquid gases. Different correction codes should be used to fight system errors, while the procedures for increasing security should be used to reduce the 
importance of intercepted bits. Additionally, extra security measures of purely technical nature may be undertaken.

Acknowledgements: This paper is part of the project by the Ministry of Education, Science and Technological Development of the Republic of Serbia, number OI 171039, TR34019, and TR32008, the Ministry of Science and Technology, Higher Education and Information Society of the Republika Srpska - the "Funding thermodynamic engineering and the development of software package for researching phonon nanostructures" project.

\section{REFERENCES}

Bennett, C. H., Brassard, G. (1984). Quantum cryptography: Public key distribution and coin tossing. Proc. IEEE Int. Conf. Computers, Systems and Signal Processing (pp. 175-179). Bangalore, India.

Bennett, C. (1992). Quantum cryptography using any two non-orthogonal states. Physical Review Letters, 68, 3121-3124.

Čisar, P (2015). Opšti aspekti kvantne kriptografije. Info $M, 14(54)$, 37-44.

Dugić, M. (2009). Osnove kvantne informatike i kvantnog računanja. Kragujevac: PMF Kragujevac.

Einstein, A., Podolsky, B., Rosen, N. (1935). Can quantum-mechanical description of physical reality be considered complete? Physical Review, 47, 777- 780.

Ekart, A. (1991). Quantum cryptography based on Bell's theorem. Physical Review Letters, 67 (6), 661-663.

Hajzenberg, V. (1974). Fizika i metafizika. Beograd: Sazvežđa.

Ijačić, S. (2014). Primena kvantne mehanike u kriptografiji, kvantno računarstvo i postkvantni šifarski sistemi, Master rad. Beograd: Univerzitet Singidunum.

Jaćimovski, S., Šetrajčić, J. (2016). Physical Fundamentals of Quantum Cryptography. Archibald Reiss Days (pp. 276-292). Belgrade: Academy of Criminalistic and Police Studies.

Jakuš, M. (2004): Kvantna kriptografija, Faculty of Electrical Engineering and Computation, Zagreb, http://os2.zemris.fer.hr/kvant/2004_jakus/

Килин С.Я., Хорошко Д.Б., Низовцев А.П. (2007). Квантовая криптография: идеи и практика. Минск: Беларуская навука.

Markagić, M. (2012). Protokoli i pravci razvoja kvantne kriptografije. Vojnotehnički glasnik, LX (1), 250-265.

Picek, S., Golub, M. (2009). Kvantna kriptografija: razvoj i protokoli. Proceedings of the Information Systems Security (str. 122-127). Opatija: MIPRO. 
Румянцев К. Е., Голубчиков Д. М. (2009). Квантовая связь и квантовая криптография. Таганрог: ТТИ ЮФУ.

Shor, P. (1994). Algorithms for quantum computation: Discrete logarithms and factoring. 35nd Annual Symposium on Foundations of Computer Science (pp. 124-134). Los Alamos: IEEE Computer Society.

Stipčević M., Kvantna kriptografija, http://www.irb.hr/users/stipcevi/download/ fer/171203.pdf (2003)

Vedral, V. (2014). Dekodiranje stvarnosti. Beograd: Laguna.

Paper received on: 20. 02. 2019.

Paper accepted for publishing on: 29. 03. 2019. 


\section{О КВАНТНОЈ КРИПТОГРАФИЈИ}

Прегледни научни рад

\begin{tabular}{|l|l|l|}
\hline DOI 10.7251/ZBK1901043J & COBISS.RS-ID 8272920 & УДК 003.26:004.056.55 \\
\hline
\end{tabular}

Стево Јаћимовски ${ }^{1}$

Криминалистичко-полицијски универзитет, Београд

Јован Шетрајчић

Факултет за спорт, Универзитет Унион-Никола Тесла, Београд

Јелена Ламовец

Институт за хемију технологију и металургију, Београд

Апстракт: Крајем двадесетог века човечанство је ушло у еру информационих технологија. ИТ индустрија, која се бави производњом, обрадом, складиштењем и преносом информација, постала је саставни део глобалног економског система, потпуно независан и прилично значајан сектор привреде. Зависност савременог друштва од информационих технологија је толико велика да пропусти у информационим системима могу довести до значајних инцидената. Телекомуникације су кључна индустрија информационих технологија. Међутим, информације су током транспорта веома осетљиве на разне врсте злоупотреба. Јединице за складиштење и обраду података могу бити физички заштићене од недобронамерних, што се не може рећи за комуникационе линије које се протежу на стотине или хиљаде километара и које је готово немогуће заштитити. Стога је проблем заштите информација у сфери телекомуникација веома значајан. Криптологија као наука и посебно њен део криптографија управо се баве овом проблематиком. Квантна криптографија је релативно новија област која се бави обезбеђењем сигурне комуникације између пошиљаоца и примаоца информације, користећи законе квантне физике. Циљ рада је да се упознамо са принципима квантне дистрибуције кључа за кодирање информација и основним проблемима који се јављају при његовој реализацији.

Кључне ријечи: криптографија, алгоритми, кодирање, кључ, квантна физика, протоколи.

\section{УВОД}

Према англосаксонској традицији учесници у кодирањи и декодирању информација се називају Алиса и Боб. Противник, који би хтео да неовлашћено сазна информације које Алиса и Боб размењују, назива се Ева од

\footnotetext{
${ }^{1}$ Аутор за кореспонденцију: др Стево Јаћимовски, редовни професор, Криминалистичкополицијски универзитет у Београду. E-mail: stevo.jacimovski@kpu.edu.rs
} 
eavedropper (прислушкивач) (Bennett, 1992). Противник, по претпоставци, располаже неограниченим рачунарским ресурсима и познаје коришћење криптографских метода, алгоритама ${ }^{2}$, протокола ${ }^{3}$ итд. (Dugić, 2009).

Класични задатак криптографије је да трансформише неки почетни текст (отворени текст) у произвољни низ знакова који се зове криптограм. Број знакова у отвореном тексту и криптограму се може разликовати. Тајност самог алгоритма кодирања ${ }^{4}$ не може, у принципу, обезбедити безусловну сигурност криптограма, јер се претпоставља да Ева (противник) има бесконачно велике рачунарске ресурсе. Стога се данас користе отворени алгоритми. Безбедност савремених криптосистема се не заснива на тајности алгоритма већ на тајности неке информације малих димензија која се назива кључ. Кључ се користи за управљање процесом кодирања и требало би да се лако може променити у било ком тренутку времена. Крајем XIX века холандски научник Керкхоф је формулисао правило по коме је сигурност кода обезбеђена ако је противнику познат целокупни систем кодирања, осим тајног кључа, тј. осим информације која управља процесом криптографске трансформације (Килин, Хорошко \& Низовцев, 2007).

\section{СИМЕТРИЧНИ МЕТОД ШИФРОВАЬА}

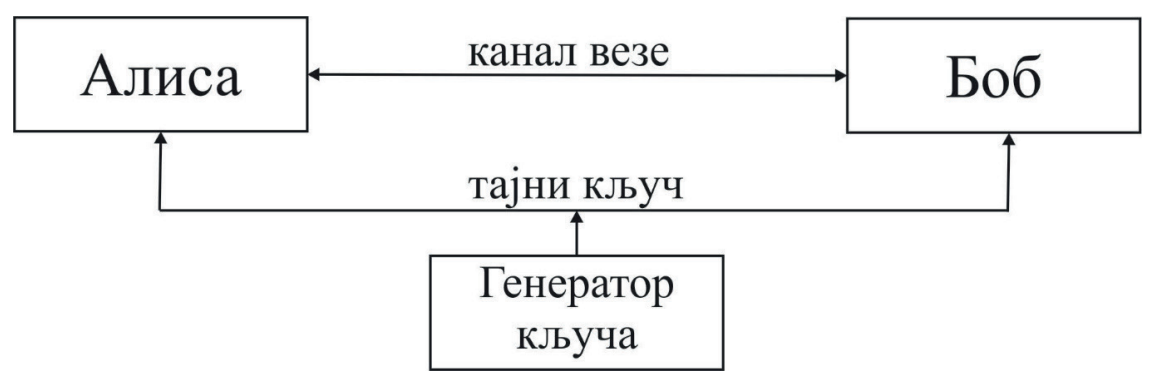

Слика 1. Структура симетричног криптосистема

Код симетричног криптосистема пошиљалац и прималац информације користе исти тајни кључ, слика 1. Помоћу тог тајног кључа се врши и шифровање и дешифровање информације. Кључ се мора периодично обнављати и истовремено дистрибуирати и пошиљаоцу и примаоцу информације. Процес дистрибуције тајних кључева између регуларних учесника

42 у размени информација је веома сложен процес. У рукама нелегитимног

\footnotetext{
${ }^{2}$ Алгоритам је скуп команди, инструкција, радњи, прорачуна које је неопходно извршити да би се из почетних података постигао неки резултат.

${ }^{3}$ Протокол је низ радњи (инструкција, команди, прорачуна, алгоритама) које се врше по одређеном редоследу од стране два или више субјеката са циљем постизања неког резултата.
}

${ }^{4}$ Кодирање тј. шифровање, енкрипција. 
корисника (Еве) тајни кључ би омогућио познавање предатих информација између Алисе и Боба (Румянцев \& Голубчиков, 2009).

Симетрични криптографски алгоритми пружају висок степен заштите све док кључ знају само пошиљалац и прималац поруке. Зато основну меру безбедности симетричних алгоритама чини метод дистрибуције кључева. Најпознатији и најраспрострањенији симетрични алгоритам је ДЕС и унапређена верзија 3 ДЕС (Čisar, 2015).

Раније је овај проблем решен некриптографском методом - преношењем кључа преко физички заштићених слушних канала. Међутим, стварање таквог канала и његово одржавање у оперативној спремности у случају хитне потребе преношења кључа је доста дуготрајно и скупо. Дакле, у условима константног повећања интензитета информационих токова, ова метода дистрибуције кључа је постајала све мање прихватљива и задовољавајућа.

Проблем је успешно решен у оквиру модерне криптографије. Постоје два начина решења дистрибуције кључа: математички и физички. Математички начин је реализован коришћењем протокола са два кључа или помоћу криптографије са отвореним кључем. Физички начин се реализује помоћу квантне криптографије.

\section{АСИМЕТРИЧНИ МЕТОД ШИФРОВАЬА}

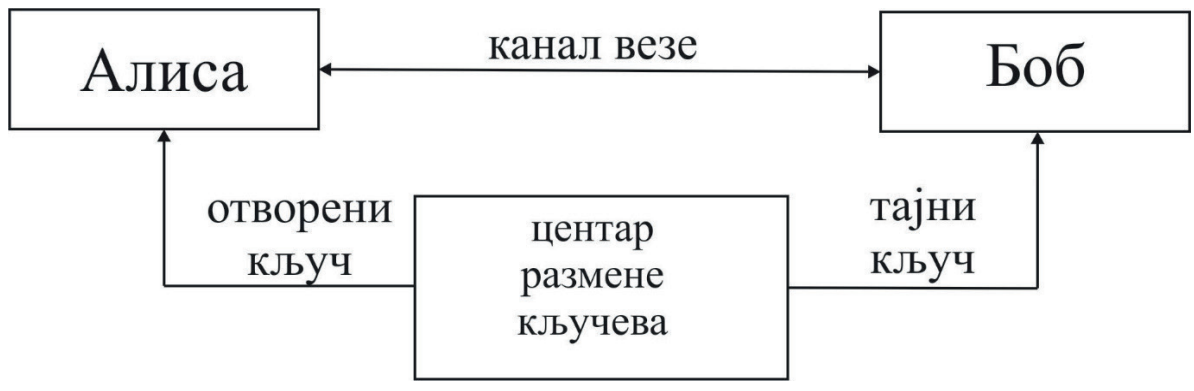

Слика 2. Структура асиметричног криптосистема

Асиметрични криптосистеми за рад користе два кључа, слика 2. Први кључ је отворен и доступан свим корисницима размене информација. Помоћу тог кључа се врши шифровање информације. Други тајни кључ поседује само прималац информације (Боб). Дешифровање информације помоћу отвореног кључа је немогуће. Такође, кључ за дешифровање није могуће одредити помоћу отвореног кључа за шифровање (Румянцев \& Голубчиков, 2009). 
Шему асиметричне криптографије су 1976. године предложили У. Дифи и М. Хелман са Станфорд универзитета. Ако Алиса и Боб желе да успоставе тајни кључ довољно је да следе овај протокол (Jakuš, 2016):

- Алиса генерише случајан број А и рачуна $P=e^{A}$ и шаље Р Бобу

- Боб генерише случајан број В и рачуна $Q=e^{B}$ и шаље $\mathrm{Q}$ Алиси

Тада Алиса и Боб рачунају тајни кључ, К, као што је приказано на слици 3.

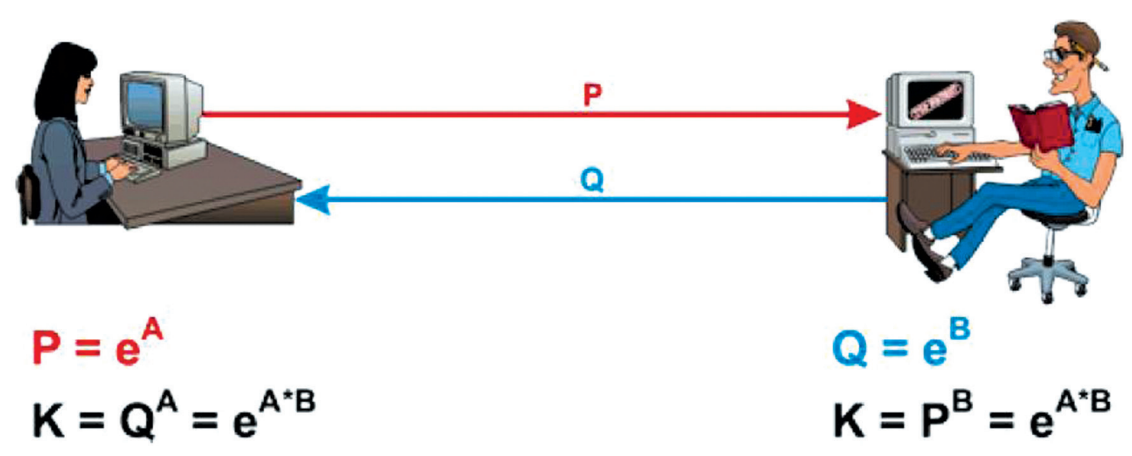

Слика 3. Дифи-Хелманов протокол

Претпоставимо да Ева поседује P и Q. Може ли израчунати К? Да би израчунала К, Ева мора израчунати А или В, јер тада може поновити рачун кључа на исти начин као Алиса односно Боб. Идеја је у томе што рачун А или В захтева рачунање дискретног логаритма:

$$
A=\ln P, B=\ln Q
$$

а за то не постоји ефикасан начин (Stipčević, 2007). Сигурност ДифиХелмановог метода заснива се на сложености дискретног логаритмовања. Најпознатији алгоритам у групи асиметричних криптографских метода је RSA.

У првом случају, у протоколу са два кључа, поступци енкрипције и дешифровања се изводе на различитим кључевима, тако да нема потребе да се тајна кључа чува. Међутим, због екстремно ниских карактеристика перформанси и излагања неким посебним врстама напада, такве шифре су се показале неприкладним за затварање директних корисничких информација.

44 Уместо тога, асиметричне шифре се користе као део комбинованих шема, када је низ података шифрован са симетричном шифром на једнократном кључу, који је пак шифрован шифром са два кључа и преноси се у овом облику заједно са подацима.

У другом случају, код криптографије са отвореним кључем, шеме дистрибуције кључа за отворене канале комуникације решавају исти про- 
блем на мало другачији начин: током интеракције, два учесника који размењују информације генеришу заједнички тајни кључ, који се затим користи за шифровање пренесених података симетричном шифром. Штавише, пресретање информација у каналу током сесије генерисања таквог кључа не дозвољава непријатељу да сам прибави кључ.

Безбедност криптосистема са два кључа заснива се на спором техничком прогресу. Њихова безбедност је заснована на проблемима факторизовања великих бројева и израчунавању дискретних логаритама у одређеним коначним групама. За те проблеме се верује да су „тешки” у смислу да не постоји бољи начин да реше него да се погађају сва могућа решења (кључеви) чиме број корака расте експоненцијално с дужином кључа.

Тајност се у савременом свету заснива на замисли да је нешто рачунарски безбедно тј. да је сигурно у смислу да би за проваљивање кода било потребно превише рачунарског времена и снаге (Vedral, 2014). За велике бројеве проналажење њиховог фактора је тежак проблем. Замислите број 100. Који су његови фактори? Два пута 50 једнако је 100. Али то важи и за 4 пута 25, или 5 пута 20 или 10 пута 10. Број фактора брзо расте и проналажење свих њих представља велику потешкоћу за сваки данашњи класични компјутер.

Ипак са очекиваном појавом квантних компјутера за које су разрађени алгоритми брзе факторизације, криптографски системи засновани на математичким методама криптозаштите могу бити угрожени.

Процедуру за ово је дао Питер Шор (Shor, 1994) који је дао алгоритам по коме квантни компјутер, пошто користи квантни принцип суперпозиције, може да постоји истовремено у много различитих стања. Замислите један једини компјутер у суперпозицији тако даје истовремено на више различитих места. На свакој од тих локација можете конфигурисати компјутер тако да дели ваш број са другим бројем како би трагали за факторима. На тај начин добијамо, огромно, невероватно убрзање решења проблема факторисања, пошто један квантни компјутер сада симултано обавља сва та дељења, по једно на свакој просторној локацији. Према мишљењу стручњака, квантни рачунар који може да разбије RSA крипто систем може да се створи за око 15-25 година.

Управо због овога дошло се на идеју да се заштита информација потражи у, колоквијално речено, ,ххардверу“ тј. да се за заштиту искористе закони квантне механике.

Стога се јавила потреба заштите криптосистема на другим основама. Решење дистрибуције кључа се остварује у квантној криптографији која је заснована на законима физике (Jaćimovski \& Šetrajčić, 2016).

Основни аргументи за ово су две чињенице:

- Немогуће је копирати непознато квантно стање 
- Без пертурбације је немогуће имати информацију о неортогоналним квантним стањима (другим речима Ева прилоком било каквог приступа каналу информације мења стање носилаца информације)

Квантна криптографија користи неодређеност квантног света у акту мерења, тзв. Хајзенбергов принцип неодређености (Hajzenberg, 1974). Уз помоћ квантне физике може се успоставити комуникациони канал који није могуће прислушкивати без ометања преноса. Два корисника који међусобно комуницирају могу увек открити присуство треће стране која покушава да сазна кључ.

Такође, особа која прислушкује не може копирати непознате квантне битове такозване кубитове, тј. непозната квантна стања, због теореме о неклонирању. Квантна криптографија служи само за добијање и дистрибуцију кључа, а не за пренос порука. Тако генерисани кључ може послужити у неком криптосистему за шифровање и дешифровање поруке.

На тај начин квантна криптографија омогућава релативно брзу размену кључева и регистровање покушаја Еве да уђе у канал везе. Нагласимо да појава грешака при предаји и пријему квантних стања не доводи обавезно до губитка тајности. За сваки протокол квантне криптографије се дефинише критична грешка изнад које тајност није обезбеђена. Ако је ниво грешака (обично се изражавају у процентима) испод критичног онда се за креирање кључа користе протоколи корекције грешака И каснијег сажимања преосталих битова. После ових поступака Ева има толико мало информација о кључу колико Алиса и Боб желе (Picek \& Golub, 2009).

У квантној криптографији се данас користе три облика кодирања квантних стања: поларизационо, фазно и кодирање са временским померањем. У раду ће се демонстрирати поступак са поларизационим кодирањем квантних стања тзв. протокол ББ84 и објаснити протокол Е91. Постоје и други протоколи квантне криптографије који се користе.

\section{Пример иройокола ББ84 без шума}

Протокол ББ84 (Bennett \& Brassard, 1984) је историјски први протокол о квантној дистрибуцији кључа (Килин, Хорошко \& Низовцев, 2007), чија је безбедност заснована на принципима квантне механике због чега је апсолутно безбедан уколико нема шума у квантном каналу везе. Одсуство шума у датој ситуацији претпоставља да се квантно стање честица не мења дуж квантног канала везе.

Протокол ББ84 је формулисан на језику појединачних фотона, слика

464 , иако се он може применити на било коју другу реализацију кубитова. За кодирање информације у протоколу се користе четири стања поларизације која образују два међусобно неортогонална базиса: Правоугаони $|\leftrightarrow\rangle$ и $|\uparrow\rangle$ и дијагонални

$$
|\nearrow\rangle=(|\leftrightarrow\rangle+|\uparrow\rangle) / \sqrt{2} \quad|\nwarrow\rangle=(|\leftrightarrow\rangle-|\uparrow\rangle) / \sqrt{2}
$$




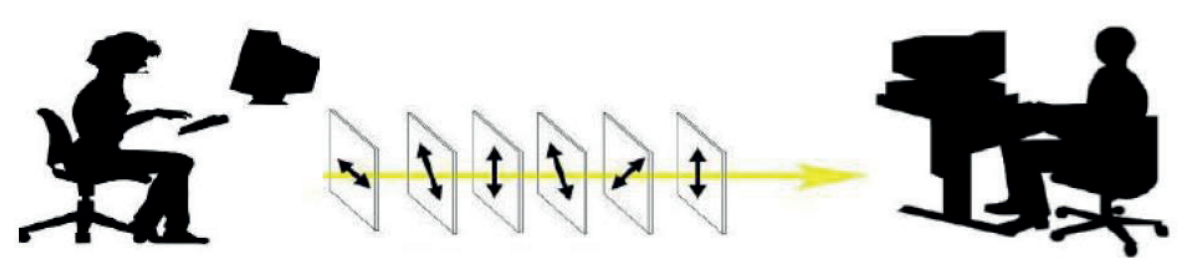

Квантни канал-слање поларизованих фотона

Слика 4. Приказ протокола ББ84

Суштина ББ84 протокола се састоји у томе да један од корисника (Алиса) бира случајно низ битова (етапа 1) и низ базиса (етапа 2) и затим шаље кориснику (Бобу) низ фотона (етапа 3 ) од којих сваки кодира један бит из изабраног низа у базису који одговара редном броју тога бита при чему стања $|\leftrightarrow\rangle|\S\rangle$ кодирају (0) нулу, а стања $|\S\rangle|\S\rangle$ јединицу (1). При добијању фотона, Боб на случајан начин, за сваки фотон и независно од Алисе, бира базис за мерење (правоугаони или дијагонални) (етапа 4) и аналогно за сваки фотон интерпретира резултат свога мерења на два начина као нулу или јединицу (етапа 5). Сагласно законима квантне механике после мерења дијагоналног фотона у правоугаоном базису, његова поларизација се претвара у хоризонталну или вертикалну и обрнуто, при чему је резултат сасвим случајан. На тај начин Боб добија резултате који се поклапају са стањима послатих фотона приближно у пола случајева (50\%), тј. када он исправно погоди базис. Следећа етапа протокола се реализује помоћу отвореног канала везе, путем кога Алиса и Боб могу отворено саопштити један другом класичну информацију. На овој етапи претпостављамо да Ева може да слуша саопштења обе стране, но не може да их мења нити да шаље обавештења уместо њих. За почетак Алиса и Боб утврђују (отвореним каналом) који су фотони успешно добијени од стране Боба и који од њих су измерени у правилном базису (етапа 6 и 7). После тога Алиса и Боб имају једнаке вредности битова, кодираних у тим фотонима, без обзира на то што та информација никада није утврђена у отвореном каналу комуникације (етапа 8). Другим речима сваки од тих фотона носи један бит случајне информације, која је позната само Алиси и Бобу и никоме више. Информације о фотонима измереним у погрешном базису се одбацују, услед чега Алиса и Боб добијају тзв. просејани кључ, који у случају да Ева није пресрела информације треба да је исти за обе стране. 


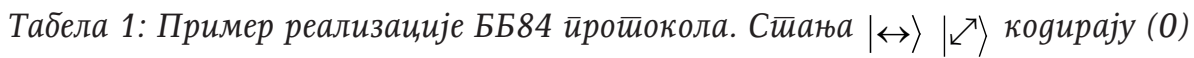
нулу, а стиаюа $|\hat{\imath}\rangle \oplus$ јеgинииу (1). Правоуїаони и gијаїонални базиси су означени са $\oplus$ и $\otimes$.

\begin{tabular}{|c|c|c|c|c|c|c|c|c|c|}
\hline Етапа 1 & $\begin{array}{l}\text { Случајни битови слања } \\
\text { (Алиса) }\end{array}$ & 0 & 1 & 1 & 0 & 1 & 1 & 0 & 0 \\
\hline Етапа 2 & $\begin{array}{l}\text { Случајни базиси слања } \\
\text { (Алиса) }\end{array}$ & $\otimes$ & $\otimes$ & $\otimes$ & $\oplus$ & $\oplus$ & $\otimes$ & $\otimes$ & $\oplus$ \\
\hline Етапа 3 & $\begin{array}{l}\text { Поларизација фотона } \\
\text { дистрибуираних по } \\
\text { квантном каналу } \\
\end{array}$ & 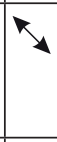 & 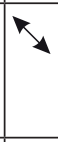 & 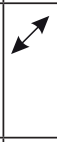 & $\leftrightarrow$ & $\uparrow$ & $\triangle$ & $\triangle$ & $\leftrightarrow$ \\
\hline Етапа 4 & $\begin{array}{l}\text { Случајни базиси пријема } \\
\text { (Боб) }\end{array}$ & $\oplus$ & $\oplus$ & $\otimes$ & $\oplus$ & $\oplus$ & $\oplus$ & $\oplus$ & $\oplus$ \\
\hline Етапа 5 & Битови које је примио Боб & 0 & 0 & 1 & 1 & 1 & 0 & 0 & 0 \\
\hline Етапа 6 & $\begin{array}{l}\text { Боб извештава Алису о } \\
\text { базисима пријема }\end{array}$ & $\oplus$ & $\otimes$ & $\otimes$ & $\otimes$ & $\oplus$ & $\oplus$ & $\oplus$ & $\oplus$ \\
\hline Етапа 7 & $\begin{array}{l}\text { Алиса одговара Бобу који } \\
\text { су им базиси усаглашени }\end{array}$ & & & & & & & & \\
\hline Етапа 8 & Просејани кључ & & & 1 & & 1 & & & 0 \\
\hline Етапа 9 & Боб открива део битова & & & & & 1 & & & \\
\hline Етапа 10 & Алиса их потврђује & & & & & & & & \\
\hline Етапа 11 & $\begin{array}{l}\text { Просејани кључ после } \\
\text { процене грешке }\end{array}$ & & & 1 & & & & & 0 \\
\hline
\end{tabular}

Претпоставимо да Ева прислушкује квантни канал. Због случајног избора правоугаоног или дијагоналног базиса Ева утиче на информацију на тај начин да мења битове просејаног кључа, који би морао бити исти за Алису и за Боба, да нема Еве. Ниједно мерење фотона од стране Еве, не даје више од једне половине информације о биту који је кодиран тим фотоном; било које такво мерење даје $b$ бита информације $(b<1 / 2)$ и није у сагласности са вероватноћом (која је у крајњем случају једнака $b / 2$, ако мерени фотон или његова замена буде измерен у почетном базису од стране Боба. На тај начин, Алиса и Боб могу проверити да ли их неко прислушкује, отворено упоређујући део битова (етапа 9 и 10) за које морају имати исту информацију иако се ти битови, надаље, не могу користити за тајни кључ. Положај битова при том упоређивању треба да је случајни подскуп правилно измерених битова, тако да присуство Еве мора да се уочи. Ако се приликом упоређивања сви упоређивани битови поклапају, јасно је да прилушкивања није било, и остатак правилно измерених битова може се користити за тајни кључ кодирања (етапа 11) и предаје података отвореним каналом.

Када се тај кључ искористи, Алиса и Боб понављају процедуру ради креирања новог тајног кључа. 


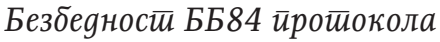

Протокол ББ84 би био угрожен ако би Ева могла да уради следеће интервенције на квантном каналу (Markagić, 2012):

1. Да измери поларизацију фотона који шаље Алиса, репродукује исти такав и пошаље га Бобу

2. Умножи фотоне које шаље Алиса

У првом случају Ева би имала исту информацију коју имају Алиса и Боб, па би на крају процедуре имала исти кључ. Међутим, Алиса користи фотоне из коњуговних база, тј. не постоји оријентација поларизатора којом би Ева могла са сигурношћу разликовати поларизацију фотона. У другом случају Ева жели с неколико различито оријентисаних поларизатора са сигурношћу одредити поларизацију фотона. Међутим, умножавање непознатог квантног стања није могуће због теореме о немогућности клонирања стања.

У комуникацији између Алисе и Боба може да се деси да ће део тачно измерених фотона бити детектован погрешно. Такође, ако Ева покуша да измери фотоне које је Алиса послала пре него што стигну до Боба, грешке ће настати због чињенице да Ева покушава да измери податке о поларизацији фотона. Ове две ситуације се не могу разликовати: природан или вештачки шум изгледају исто. Услед тога Алиса и Боб се договарају о мањем криптографском кључу у три фазе. Те три фазе називају се процена грешке, поравнање информација и појачање приватности.

\section{Пройокол Е91 (Ekart, 1991)}

Даље побољшање поузданости криптосистема може се постићи употребом Ајнштајн-Подолски-Розен (АПР) ефекта (Einstein, Podolsky \& Rosen, 1935). АПР ефекат се дешава када сферно симетрични атом зрачи два фотона у супротним правцима према два посматрача. Фотони се емитују са неодређеном поларизацијом, али су због симетрије њихове поларизације увек супротне (ефекат квантне сплетености). Важна карактеристика овог ефекта је да поларизација фотона постаје позната тек након мерења. На основу АПР-а, Екерт је предложио крипто-шему која гарантује сигурност преноса и складиштења кључа. Пошиљалац генерише бројне АПР фотонске парове. За себе оставља по један фотон из сваког пара, а другог шаље свом партнеру. Истовремено, ако је ефикасност регистрације близу јединства, када пошиљалац прими вредност поларизације 1, његов партнер ће регистровати вредност 0 и обрнуто. Јасно је да на овај начин партнери, кад год је потреб́о, могу добити идентичне псеудо-случајне кодне секвенце. Практично, имплементација ове шеме је проблематична због ниске ефикасности снимања и мерења поларизације једног фотона. 


\section{ЗАКљУЧАК}

Задатак криптографије је размена тајних порука. Постоје класични методи који гарантују практично сигурну (безбедну) комуникацију (између Алисе и Боба), уколико је обема странама познат тајни кључ за дешифровање, и истовремено, тај кључ није никоме другом познат, па ни потенцијалном противнику, Еви.

Управо та претпоставка о тајности „тајног кључа“ је најслабија карика у класичној криптографији. Једини задатак квантне криптографије је обезбеђивање тајног кључа. Дакле, у квантној криптографији се не размењују поруке већ само тајни кључ, путем тзв. квантног канала. Данас већ постоје комерцијални уређаји као и десетине имплементација државних и корпоративних сигурних комуникационих мрежа које примењују технологије дистрибуције квантног кључа. Предности ових технологија су безусловна сигурност која се заснива на феноменима квантне механике. Данас је практично могуће, уз безусловну сигурност, генерисати и дистрибуирати тајни кључ између две стране повезане оптичким влакном на удаљеностима до 150 километара за неколико секунди. Прислушкивање комуникације од треће стране не доводи до открића тајне него искључиво до смањења брзине генерисања кључева, с тим да обе стране одмах знају да је линија активно прислушкивана. Главни недостаци ових система су ограничење брзине генерисања кључа која директно зависи од удаљености учесника, немогућност појачавања сигнала односно преношења путем неке врсте релеја, практично ограничење искључиво на комуникације путем оптичких влакана, као и цена имплементација система (Ijačić, 2014).

У идеалним системима квантне комуникације, пресретање података је немогуће, јер пресретање учесници у размени одмах откривају као грешке које се јављају у преносу. Међутим, прави системи су различити од идеалних.

За разлику од идеалног, стварни квантни комуникацијски системи нису у стању да осигурају апсолутну тајност пренесених података. То је због чињенице да у систему постоји фон сопствених грешака, иза којег се могу прикрити покушаји пресретања информација, као и пригушење у комуникацијским каналима због неопходности коришћења мултифотонских импулса. Коришћење јаких импулса фотона доводи до пригушења преноса информација што омогућава неприметно пресретање података. То је практично фактор који се не може уклонити, будући да се квалитет канала којим се информација преноси не може увек контролисати.

На путу ка практичној примени квантних комуникационих система треба решити низ техничких потешкоћа као што су развој стабилних извора појединачних фотона и једнофотонских детектора који би радили у нормалном температурном опсегу и не би требало да буду хлађени течним гасовима. За борбу против системских грешака треба користити различите корекционе кодове, а за смањење значаја пресретнутих битова користити про- 
цедуре за повећање тајности. Поред тога, могу се предузети додатне мере безбедности чисто техничке природе.

Захвалност: Овај рад је урађен у оквиру пројеката Министарства просвете, науке и технолошког развоја Републике Србије, број ОИ 171039 , ТР34019 и ТР32008, Министарства за научнотехнолошки развој, високо образовање и информационо друштво Републике Српске, пројекат „Фундирање термодинамичког инжењеринга и развој софтверског пакета за истраживање фононских наноструктура“.

\section{ЛИТЕРАТУРА}

Bennett, C. H., Brassard, G. (1984). Quantum cryptography: Public key distribution and coin tossing. Proc. IEEE Int. Conf. Computers, Systems and Signal Processing (pp. 175-179). Bangalore, India.

Bennett, C. (1992). Quantum cryptography using any two non-orthogonal states. Physical Review Letters, 68, 3121-3124.

Čisar, P (2015). Opšti aspekti kvantne kriptografije. Info $M, 14(54)$, 37-44.

Dugić, M. (2009). Osnove kvantne informatike i kvantnog računanja. Kragujevac: PMF Kragujevac.

Einstein, A., Podolsky, B., Rosen, N. (1935). Can quantum-mechanical description of physical reality be considered complete? Physical Review, 47, 777- 780.

Ekart, A. (1991). Quantum cryptography based on Bell's theorem. Physical Review Letters, 67 (6), 661-663.

Hajzenberg, V. (1974). Fizika i metafizika. Beograd: Sazvežđa.

Ijačić, S. (2014). Primena kvantne mehanike u kriptografiji, kvantno računarstvo i postkvantni šifarski sistemi, Master rad. Beograd: Univerzitet Singidunum.

Jaćimovski, S., Šetrajčić, J. (2016). Physical Fundamentals of Quantum Cryptography. Archibald Reiss Days (pp. 276-292). Belgrade: Academy of Criminalistic and Police Studies.

Jakuš, M. (2004): Kvantna kriptografija, Faculty of Electrical Engineering and Computation, Zagreb, http://os2.zemris.fer.hr/kvant/2004_jakus/

Килин С.Я., Хорошко Д.Б., Низовцев А.П. (2007). Квантовая криптография: идеи и практика. Минск: Беларуская навука.

Markagić, M. (2012). Protokoli i pravci razvoja kvantne kriptografije. Vojnotehnički glasnik, LX (1), 250-265.

Picek, S., Golub, M. (2009). Kvantna kriptografija: razvoj i protokoli. Proceedings of the Information Systems Security (str. 122-127). Opatija: MIPRO. 
Румянцев К. Е., Голубчиков Д. М. (2009). Квантовая связь и квантовая криптография. Таганрог: ТТИ ЮФУ.

Shor, P. (1994). Algorithms for quantum computation: Discrete logarithms and factoring. 35nd Annual Symposium on Foundations of Computer Science (pp. 124-134). Los Alamos: IEEE Computer Society.

Stipčević M., Kvantna kriptografija, http://www.irb.hr/users/stipcevi/download/ fer/171203.pdf (2003)

Vedral, V. (2014). Dekodiranje stvarnosti. Beograd: Laguna.

Рад примљен: 20. 02. 2019.

Рад прихваћен: 29. 03. 2019. 